\title{
Heavy metal levels in spent engine oils and fingernails of auto-mechanics
}

\author{
Chris Oche IKESE ${ }^{*}{ }^{1}$ Peter Agorye ADIE,${ }^{1}$ Christie ADAH,${ }^{1}$ Raphael AMOKAHA,${ }^{2}$ Grace ABU,${ }^{1}$ \\ and Timothy YAGER $^{1}$
}

\author{
${ }^{1}$ Department of Chemistry, Benue State University, Makurdi, Nigeria \\ ${ }^{2}$ Department of Biochemistry, Benue State University, Makurdi, Nigeria
}

\begin{abstract}
The levels of some heavy metals in spent engine oils and in the fingernails of auto-mechanics were studied. Engine oils and fingernails were collected from auto-mechanics who had practiced between $\leq 5$ years, $\leq 10$ years and $\leq$ 15 years in 3 auto-mechanic workshop clusters. $\mathrm{Pb}, \mathrm{Ni}, \mathrm{V}, \mathrm{Cd}$, and As levels were determined using Atomic Absorption Spectrophotometer. The mean levels of $\mathrm{Pb}, \mathrm{Ni}, \mathrm{V}$ and $\mathrm{Cd}$ in spent engine oils were 14.31, 2.25, 0.38 and $2.07 \mathrm{ppm}$ respectively, and these far exceeded their permissible exposure limits. The mean levels of heavy metals in the fingernails of auto-mechanics who had practiced for $\leq 5$ years, $\leq 10$ years and $\leq 15$ years were all considerably below their pathological thresholds. Thus, auto-mechanics in the study area are exposed to unsafe levels of $\mathrm{Pb}, \mathrm{Ni}, \mathrm{V}$, and $\mathrm{Cd}$, but no immediate threat of their toxicities in the study population exist. However, a progressive bioaccumulation of the heavy metals was observed with increase in years of practice.
\end{abstract}

Keywords: auto-mechanics; heavy metals; fingernails; spent engine oil; occupational exposure.

\section{Introduction}

Industrialization and economic growth have continued to create a growing need for the movement of people, goods and services from place to place [1-3]. This has contributed to the growing number of automobiles in use [4] as well as the number of auto-mechanics required to maintain them, such that the demand for auto-mechanics exceeds their supply [5-8]. However, in Nigeria, the supply of auto mechanics is believed to exceed their demand. The presence of $\mathrm{Pb}$ and other heavy metals in petrol, engine oil and car exhaust gases constitute some of the major sources of exposure of auto-mechanics to these heavy metals [9]. In mechanic workshops, heavy metal exposure occurs via nasal, oral and dermal routes [10]. Rising levels of these heavy metals in body tissues such as fingernail, blood and hair, of auto-mechanics may indicate their bioaccumulation from frequent occupational exposure [4], thus threatening the health and wellbeing of the limited number of people that constitute this peculiar workforce. Several studies have been carried out to determine the levels of heavy metals in auto-mechanic workshop soils [11-15], work clothes [4], engine oils [16], fingernail, hair [17, 18] and blood [19] as well as other samples linked with automechanics and several other populations exposed to heavy metals. All of such studies have reported varying levels of exposures that are mostly affected by a combination of factors peculiar to the study area, such as: the attitude of the study population to the use of protective gear, level of compliance with workplace safety precautions, level of existing awareness on ergonomic sources of exposure to heavy metals among others. For instance, Sani et al. [4] reported that in Africa, most auto-mechanics are not using the needed safety kits such as goggles, safety garb etc. In fact, auto- mechanics use the same work-cloth for several months without washing. Also, as a result of inadequate equipment and working tools, mechanics often use their bare hands in most of their work resulting in adsorption of different contaminants into their skins. This is perhaps why it is important that, in order to actually ascertain the levels of exposure to heavy metals among auto-mechanics, such studies should be done in workshop clusters among auto-mechanics who operate under a similar set of conditions.

Although it is recognized that auto-mechanics are exposed to various types of hazardous substances, priority is often given to lead, nickel, vanadium, cadmium and arsenic because of the several sources of these heavy metals in automobile-workshops, ranging from spent engine oils, contaminated work clothes, contaminated workshop soils, materials used in the fabrication of auto-mobile parts, to the various petroleum products that are required for the smooth operation of vehicles [20, 21]. Spent engine oil refers to engine oil after it has been used for lubrication in vehicle engine. It has been reported that blood and other fluids present in the human body give transient concentrations of these analytes, this may be due to xenobiotic metabolism or their incorporation into bone tissue but human nails provide a continuous record of elemental exposure [22] as they provide a longer integration period for heavy metals. The use of nails as a biomarker of occupational exposure to heavy metals in the body is preferred also because, they are regarded as good bioindicators for several toxic elements to which workers had been exposed from all routes [23] for a duration of at least two to eighteen months [24]. Heavy metal accumulation in high amounts within the body can have severe health implications and may be lethal in severe

\footnotetext{
* Corresponding author. E-mail address: chrisjieng@yahoo.com (C. O. Ikese)
} 
cases $[9,10]$, as such, the exposure of auto mechanics to them must be determined as an empirical basis for the enforcement of safety protocols for use in such work environments. This study is one such study which seeks to determine, the concentrations of selected heavy metals in the spent engine oils which auto-mechanics routinely come into direct contact with, as well as the concentrations of same in their fingernails in order to ascertain the level of occupational exposure of these group of workers to heavy metals in their workplace.

\section{Experimental}

\subsection{Materials}

All reagents and standards used were of analytical grade and supplied by BDH, UK. Also, $1000 \mathrm{mg} / \mathrm{L}$ solution each of $\mathrm{Pb}, \mathrm{Ni}, \mathrm{V}, \mathrm{Cd}$, and $\mathrm{As}$ was used for the preparation of working standards. All glassware, porcelain and plastic wares were washed four times using deionized water, before soaking them in $20 \% \mathrm{v} / \mathrm{v}$ $\mathrm{HNO}_{3}$ for $24 \mathrm{~h}$. Thereafter, the laboratory wares were rinsed four times in deionized water and oven-dried at $90{ }^{\circ} \mathrm{C}$ for $8 \mathrm{~h}$.

\subsection{Sample collection and pre-treatment}

Three auto-mechanic workshop clusters in Makurdi (North-bank, New garage and Apir, coded as A, B and $\mathrm{C}$ respectively) located in Benue State, within the NorthCentral part of Nigeria were chosen for the study. Fifteen sampling stations were selected within each workshop cluster. In each of the auto-mechanic workshop clusters A, B and C, $5 \mathrm{~mL}$ each of spent and unspent engine oils were separately collected from 15 automobile workshops during routine automobile oil replacement. Pre-cleaned $5 \mathrm{~mL}$ syringes were used for the sample collection. Thereafter, each category of engine oil samples (spent and unspent) from a given cluster were composited into 3 groups of $25 \mathrm{~mL}$ sample triplicate and stored in prewashed glass bottles until needed for heavy metals analysis.

In each of the auto-mechanic workshop clusters A, $\mathrm{B}$ and $\mathrm{C}$, fingernail samples were collected from all 10 fingers of each of the 30 auto-mechanics randomly selected per cluster by trimming with clean stainlesssteel nail-cutters. The fingernail samples were then composited in triplicates according to the durations of practice of the auto-mechanics, namely: short, medium and long terms $(\leq 5$ years, $\leq 10$ years and $\leq 15$ years respectively). The pre-digestion washing of the nail samples were done in a previously cleaned beaker for 15 minutes using $160 \mathrm{~mL}$ distilled acetone/hexane $(3 / 5$, $\mathrm{v} / \mathrm{v}$ ) for $24 \mathrm{~h}$, before being washed repeatedly with deionized water and oven dried at $120{ }^{\circ} \mathrm{C}$ for $30 \mathrm{~min}$. This was to remove external contaminants [4, 25, 26]. The oven-dried samples were pulverized into a fine powder using an acid-washed porcelain mortar before storing away in clean plastic containers until needed for heavy metals analysis.

\subsection{Heavy metals analysis}

The instrumental methods reported by Pam et al. [13] and Jacob et al. [27] were adapted for the determination of heavy metals in the engine oil samples in this study. Using a micropipette, $1 \mathrm{~mL}$ of each of the composite engine oil samples were separately transferred into 25 $\mathrm{mL}$ acid washed, volumetric flasks, each containing 15 $\mathrm{mL}$ concentrated $\mathrm{HNO}_{3}$ and slowly evaporated over a period of $9 \mathrm{~h}$ on a heating mantle. Each residue obtained was digested with $15 \mathrm{~mL} 3: 1 \mathrm{v} / \mathrm{v}$ concentrated $\mathrm{HNO}_{3}$ and $\mathrm{HClO}_{4}$ mixture for $8 \mathrm{~h}$ at room temperature before heating intermittently on a heating mantle to ensure a steady temperature of $150{ }^{\circ} \mathrm{C}$ was maintained for over 6 h until the $\mathrm{HClO}_{4}$ fumes were completely evaporated. Each mixture was separately allowed to cool to room temperature before filtering into a $50 \mathrm{~mL}$ volumetric flask using Whatman No. 1 filter paper and making up to the mark with deionized water, following quantitative rinsing of the reacting vessels. The solution of the sample filtrate was then stored in pre-cleaned amber bottles until instrumental analysis. $\mathrm{Pb}, \mathrm{Ni}, \mathrm{V}, \mathrm{Cd}$, and $\mathrm{As}$ levels in each sample diluent was determined in three repetitions for each sample using an Atomic absorption spectrophotometer (Phoenix-986, Biotech engineering, UK). The instrument was calibrated with analytical grade standard metal solutions $\left(1 \mathrm{mg} / \mathrm{dm}^{3}\right)$ and the instrument operated following the manufacturer's operational instructions. The mean levels of each heavy metal in the samples from each location were computed and statistically compared using One-way ANOVA for significant differences and thereafter, compared with set permissible exposure limits.

The instrumental methods reported by Mehra et al. [28] and Rashed et al. [17] were adapted for the determination of the heavy metals in fingernail samples in this study. $0.1 \mathrm{~g}$ amount of each category of the pulverised fingernail sample was digested in $5 \mathrm{~mL}$ concentrated $\mathrm{HNO}_{3} / \mathrm{HCl}$ (3:1) acid mixture and allowed to stand at room temperature overnight before heating to near dryness on a heating mantle. Thereafter, $2 \mathrm{~mL} \mathrm{19 \%}$ $\mathrm{HNO}_{3}$ was added to the sample digest and dissolved with deionised water and then made up to the mark in a $10 \mathrm{~mL}$ volumetric flask with more deionised water. The above procedure was repeated for the standard and reagent blank sample used to calibrate the equipment. $\mathrm{Pb}, \mathrm{Ni}, \mathrm{V}, \mathrm{Cd}$, and As concentrations were measured in the fingernail sample solutions by flame atomic absorption spectrophotometer (Phoenix-986, Biotech engineering, UK) following the instrument manufacturer's instruction. The mean level of the heavy metals determined in the fingernail samples were statistically compared according to clusters and by duration of practice for any significant difference using One-way ANOVA, and thereafter compared with set pathological limits established by regulatory bodies.

\subsection{Statistical analysis}

SPSS-statistics version 22.0 was used to calculate the mean \pm standard deviations of the concentrations of heavy metals determined in engine oil and fingernails samples as well as to compare them by location and duration of practice using One-way ANOVA.

\section{Results and discussion}

Table 1 shows the concentration of some heavy metals in spent and unspent engine oils in Makurdi metropolis, and it can be seen from it that, unspent engine oils have 
the lowest level of all the heavy metals in the study. This is an indication that, with usage in automobile engines, engine oils become laden with more heavy metals.

Table 1. Heavy metal concentrations in spent and unspent engine oils in Makurdi Metropolis

\begin{tabular}{|c|c|c|c|c|c|c|}
\hline SN & $\begin{array}{c}\text { Type of } \\
\text { engine oil and } \\
\text { source }\end{array}$ & $\begin{array}{c}\mathbf{P b} \\
(\mathbf{p p m})\end{array}$ & $\begin{array}{c}\mathbf{N i} \\
(\mathbf{p p m})\end{array}$ & $\begin{array}{c}\mathrm{V} \\
(\mathbf{p p m})\end{array}$ & $\underset{(\mathbf{p p m})}{\mathbf{C d}}$ & $\begin{array}{c}\text { As } \\
(\mathbf{p p m})\end{array}$ \\
\hline 1 & $\begin{array}{l}\text { Spent engine } \\
\text { oil - Cluster A }\end{array}$ & $\begin{array}{l}12.22^{\mathrm{a}} \\
\pm 1.25\end{array}$ & $\begin{array}{l}1.73^{\mathrm{m}} \\
\pm 0.39\end{array}$ & $\begin{array}{l}0.26^{\mathrm{P}} \\
\pm 0.07\end{array}$ & $\begin{array}{l}1.94^{\mathrm{e}} \\
\pm 0.27\end{array}$ & N. D. \\
\hline 2 & $\begin{array}{l}\text { Spent engine } \\
\text { oil - Cluster B }\end{array}$ & $\begin{array}{l}16.64^{\mathrm{b}} \\
\pm 1.96\end{array}$ & $\begin{array}{l}1.83^{\mathrm{m}} \\
\pm 0.33\end{array}$ & $\begin{array}{l}0.66^{q} \\
\pm 0.18\end{array}$ & $\begin{array}{l}1.98^{\mathrm{e}} \\
\pm 0.10\end{array}$ & N. D. \\
\hline 3 & $\begin{array}{l}\text { Spent engine } \\
\text { oil - Cluster C }\end{array}$ & $\begin{array}{l}14.09^{a} \\
\pm 0.68\end{array}$ & $\begin{array}{l}3.21^{\mathrm{n}} \\
\pm 0.25\end{array}$ & $\begin{array}{l}0.23^{\mathrm{p}} \\
\pm 0.05\end{array}$ & $\begin{array}{l}2.30^{\mathrm{f}} \\
\pm 0.33\end{array}$ & N. D. \\
\hline 4 & $\begin{array}{l}\text { Unspent } \\
\text { engine oil }\end{array}$ & $\begin{array}{l}8.07^{\mathrm{d}} \\
\pm 0.13\end{array}$ & $\begin{array}{l}1.35^{\mathrm{p}} \\
\pm 0.03\end{array}$ & $\begin{array}{l}0.14^{\mathrm{r}} \\
\pm 0.00\end{array}$ & $\begin{array}{l}1.16^{\mathrm{e}} \\
\pm 0.03\end{array}$ & N. D. \\
\hline
\end{tabular}

Values are reported as mean \pm SD of four determinations.

Means with identical superscripts within a column are not significantly different at $p=0.05$.

From Table 1 it can be seen that there is significant difference between the concentrations of heavy metals in spent engine oils across the 3 workshop clusters and there exists a significant high difference in the concentration of heavy metals present in spent engine oil compared with that in unspent engine oils regardless of the study location (cluster). This implies that the use of engine oils in vehicle engines lead to further accumulation of these heavy metals in spent engine oils, thus increasing the amount of these heavy metals that auto-mechanics are exposed to in the course of vehicle maintenance. Also, Table 1 shows that, whereas the highest concentrations of $\mathrm{Pb}, \mathrm{Ni}, \mathrm{V}$ and $\mathrm{Cd}$, (16.64, 3.21, 0.66 , and $2.30 \mathrm{ppm}$ respectively), were recorded in spent engine oils, their lowest concentrations $(8.07,1.35,0.14$, and $1.16 \mathrm{ppm}$ respectively) were recorded in unspent engine oil. This implies that the major determinant of exposure to heavy metals from engine oil is in the nature of the spent engine oils rather than in the nature of the cluster. Arsenic on the other hand was not detected in any of the samples. This implies that, auto mechanics are not at risk of As exposure both from spent and unspent engine oil sources.

Table 2. Mean heavy metal concentration in spent engine oils in Makurdi and their exposure limits

\begin{tabular}{ccccc}
\hline SN & $\begin{array}{c}\text { Heavy } \\
\text { metal }\end{array}$ & $\begin{array}{c}\text { Heavy metal } \\
\text { concentration } \\
\text { (ppm) }\end{array}$ & \multicolumn{2}{c}{$\begin{array}{c}\text { Exposure limit } \\
\text { (ppm) [29] }\end{array}$} \\
& & OSHA & $\begin{array}{c}\text { ACGIH } \\
\text { PEL }\end{array}$ & TLV \\
\hline 1 & $\mathrm{~Pb}$ & $14.31 \pm 2.21$ & 0.01 & 0.01 \\
2 & $\mathrm{Ni}$ & $2.25 \pm 0.82$ & 0.21 & 0.62 \\
3 & $\mathrm{~V}$ & $0.38 \pm 0.24$ & 0.02 & 0.02 \\
4 & $\mathrm{Cd}$ & $2.07 \pm 0.19$ & 0.02 & 0.02 \\
5 & $\mathrm{As}$ & $\mathrm{N} . \mathrm{D}$. & - & - \\
\hline
\end{tabular}

Values are reported as mean \pm SD of triplicate determinations.

OSHA PEL - United States Occupational Safety and Health Administration Permissible Exposure Limit for an 8-hour time weighted average
ACGIH TLV - American Conference of Governmental Industrial Hygienists Threshold limit value

Table 2 provides a comparison between the mean heavy metal concentration in spent engine oils and their exposure limits. The results demonstrate clearly that, the mean levels of these heavy metals in spent engine oils are higher than their exposure limits. Table 2 shows that, the mean levels of $\mathrm{Pb}, \mathrm{Ni}, \mathrm{V}$, and $\mathrm{Cd}$ in spent engine oils are $14.31,2.25,0.38$, and $2.07 \mathrm{ppm}$ respectively. With the exception of As which was not detected, each of these concentrations far exceed both their permissible exposure limit and their threshold limit value. The implication is that auto-mechanics in all 3 workshop clusters are exposed to unsafe levels of $\mathrm{Pb}, \mathrm{Ni}, \mathrm{V}$, and $\mathrm{Cd}$. Hence, it is only a matter of time before heavy metal toxicities will begin to manifest from prolonged bioaccumulation of the heavy metals.

Table 3 shows the heavy metal concentrations in fingernails of auto-mechanics based on their duration of practice and demonstrates that there is increased heavy metal concentration in auto-mechanics who have practiced for a longer duration. Notably, the heavy metals concentrations are particularly higher in cluster B. Also, auto-mechanics who have practiced for $\leq 15$ years, are seen to have the highest concentrations of the heavy metals. From Table 3 , the concentration of the five heavy metals analysed is in the order; $\mathrm{Pb}>\mathrm{Ni}>\mathrm{Cd}$ $>\mathrm{V}>\mathrm{As}$ and this is because of the use of $\mathrm{Pb}$ in higher quantities in the fabrication of automobile parts as well as lapses in the refining process of petroleum, resulting in its presence in fuels and lubricants. However, this result trend is in contrast with a study by Nada et al. [31] where $\mathrm{Ni}$ was highest in concentration and $\mathrm{Cd}$ was lowest. This is likely due to variation in the combination of heavy metals assessed in both studies. Also, the highest concentrations of all the heavy metals assessed were observed in the category of auto-mechanics who had practiced for a period of $\leq 15$ years and this is indicative of a greater bioaccumulation of heavy metals from longer duration of exposure on the job. $\mathrm{Pb}, \mathrm{Ni}, \mathrm{Cd}$, and $\mathrm{V}$ were found in fingernail samples from all the study locations (clusters A, B and C) except arsenic, this implies that there is no potential for As toxicity among this category of workers. The peak concentration for the heavy metals present were mostly found in automechanics who had practiced for more than ten years in all three mechanic workshop clusters and particularly higher in auto-mechanics in cluster B. This may be due to the referral status of cluster $\mathrm{B}$ workshops and the associated high volume of maintenance work that is carried out there. The observed distribution trend in the heavy metal levels in the study locations is cluster B > cluster $\mathrm{C}>$ cluster $\mathrm{A}$.

Table 3. Heavy metal concentration in fingernails of auto-mechanics by duration of practice

\begin{tabular}{|c|c|c|c|c|c|c|c|c|c|c|c|c|c|c|c|}
\hline \multirow[b]{2}{*}{$\begin{array}{c}\text { Workshop } \\
\text { cluster }\end{array}$} & \multicolumn{3}{|c|}{ Pb (ppm) } & \multicolumn{3}{|c|}{ Ni (ppm) } & \multicolumn{3}{|c|}{$\mathbf{V}$ (ppm) } & \multicolumn{3}{|c|}{ Cd (ppm) } & \multicolumn{3}{|c|}{ As (ppm) } \\
\hline & $\begin{array}{c}<5 \\
\text { years }\end{array}$ & $\begin{array}{c}5-10 \\
\text { years }\end{array}$ & $\begin{array}{l}10-15 \\
\text { years }\end{array}$ & $\begin{array}{c}<5 \\
\text { years }\end{array}$ & $\begin{array}{c}5-10 \\
\text { years }\end{array}$ & $\begin{array}{l}10-15 \\
\text { years }\end{array}$ & $\begin{array}{c}<5 \\
\text { years }\end{array}$ & $\begin{array}{c}5-10 \\
\text { years }\end{array}$ & $\begin{array}{l}10-15 \\
\text { years }\end{array}$ & $\begin{array}{c}<5 \\
\text { years }\end{array}$ & $\begin{array}{c}5-10 \\
\text { years }\end{array}$ & $\begin{array}{l}10-15 \\
\text { years }\end{array}$ & $\begin{array}{c}<5 \\
\text { years }\end{array}$ & $\begin{array}{c}5-10 \\
\text { years }\end{array}$ & $\begin{array}{l}10-15 \\
\text { years }\end{array}$ \\
\hline A & $\begin{array}{c}0.041^{\mathrm{a}} \\
\pm 0.002\end{array}$ & $\begin{array}{l}0.087^{\mathrm{c}} \\
\pm 0.004\end{array}$ & $\begin{array}{l}0.195^{\mathrm{p}} \\
\pm 0.010\end{array}$ & $\begin{array}{l}0.012^{\mathrm{c}} \\
\pm 0.003\end{array}$ & $\begin{array}{l}0.023^{\mathrm{g}} \\
\pm 0.003\end{array}$ & $\begin{array}{l}0.070^{x} \\
\pm 0.001\end{array}$ & $\begin{array}{l}0.007^{\mathrm{B}} \\
\pm 0.002\end{array}$ & $\begin{array}{l}0.013^{\mathrm{m}} \\
\pm 0.001\end{array}$ & $\begin{array}{l}0.023^{\mathrm{g}} \\
\pm 0.002\end{array}$ & $\begin{array}{l}0.0^{1} 11 \\
\pm 0.002\end{array}$ & $\begin{array}{l}0.016^{\mathrm{a}} \\
\pm 0.001\end{array}$ & $\begin{array}{l}0.026 \\
\pm 0.002\end{array}$ & N.D & N.D & N.D \\
\hline B & $\begin{array}{l}0.024^{\mathrm{b}} \\
\pm 0.001\end{array}$ & $\begin{array}{l}0.070^{\mathrm{c}} \\
\pm 0.001\end{array}$ & $\begin{array}{l}0.149^{9} \\
\pm 0.003\end{array}$ & $\begin{array}{l}0.009^{\circ} \\
\pm 0.001\end{array}$ & $\begin{array}{l}0.018^{\mathrm{k}} \\
\pm 0.002\end{array}$ & $\begin{array}{l}0.053^{y} \\
\pm 0.002\end{array}$ & $\begin{array}{l}0.007^{\mathrm{e}} \\
\pm 0.001\end{array}$ & $\begin{array}{l}0.011^{\mathrm{b}} \\
\pm 0.001\end{array}$ & $\begin{array}{l}0.018^{g} \\
\pm 0.001\end{array}$ & $\begin{array}{l}0.007^{1} \\
\pm 0.001\end{array}$ & $\begin{array}{l}0.011^{\mathrm{b}} \\
\pm 0.001\end{array}$ & $\begin{array}{l}0.040^{k} \\
\pm 0.004\end{array}$ & N.D & N.D & N.D \\
\hline C & $\begin{array}{c}0.01^{\mathrm{p}_{ \pm}} \\
0.003\end{array}$ & $\begin{array}{l}0.060^{\mathrm{p}} \\
\pm 0.003\end{array}$ & $\begin{array}{l}0.215^{r} \\
\pm 0.006\end{array}$ & $\begin{array}{l}0.013^{\circ} \\
\pm 0.001\end{array}$ & $\begin{array}{l}0.022^{\mathrm{k}} \\
\pm 0.002\end{array}$ & $\begin{array}{l}0.041^{z} \\
\pm 0.002\end{array}$ & N.D & $\begin{array}{l}0.011^{\mathrm{m}} \\
\pm 0.001\end{array}$ & $\begin{array}{l}0.020^{\mathrm{g}} \\
\pm 0.003\end{array}$ & $\begin{array}{l}0.012^{\mathrm{r}} \\
\pm 0.001\end{array}$ & $\begin{array}{l}0.019^{\mathrm{a}} \\
\pm 0.002\end{array}$ & $\begin{array}{l}0.029^{1} \\
\pm 0.001\end{array}$ & N.D & N.D & N.D \\
\hline
\end{tabular}

Values are means \pm SD of duplicate determinations. 
Table 4. Mean levels of some heavy metal in the fingernails of auto-mechanics and their reference /pathological values

\begin{tabular}{|c|c|c|c|c|c|c|}
\hline $\mathbf{S} / \mathbf{N}$ & $\begin{array}{c}\text { Heavy } \\
\text { metal }\end{array}$ & $\begin{array}{l}\leq 5 \text { years } \\
(\mathrm{ppm})\end{array}$ & $\begin{array}{l}\leq 10 \text { years } \\
(\mathrm{ppm})\end{array}$ & $\begin{array}{l}\leq 15 \text { years } \\
(\mathrm{ppm})\end{array}$ & $\begin{array}{c}\text { Reference values [30] } \\
(\mathbf{p p m})\end{array}$ & $\begin{array}{l}\text { Pathological values [30] } \\
\text { (ppm) }\end{array}$ \\
\hline 1 & $\mathrm{~Pb}$ & $0.028^{\mathrm{a}} \pm 0.012$ & $0.072^{a} \pm 0.014$ & $0.187^{b} \pm 0.034$ & 2.0 & $>2.0$ \\
\hline 2 & $\mathrm{Ni}$ & $0.011^{\mathrm{k}} \pm 0.002$ & $0.021^{\mathrm{k}} \pm 0.003$ & $0.055^{\mathrm{i}} \pm 0.015$ & 5.0 & $>5.0$ \\
\hline 3 & V & $0.005^{\mathrm{p}} \pm 0.004$ & $0.012^{\mathrm{p}} \pm 0.001$ & $0.020^{\mathrm{q}} \pm 0.003$ & $0.01-0.21$ & $>0.21$ \\
\hline 4 & $\mathrm{Cd}$ & $0.010^{c} \pm 0.003$ & $0.015^{\mathrm{c}} \pm 0.004$ & $0.032^{\mathrm{d}} \pm 0.007$ & 0.14 & $>0.14$ \\
\hline 5 & As & N. D. & N. D. & N. D. & $<0.87$ & $>0.87$ \\
\hline
\end{tabular}

Values are means \pm SD of triplicate determinations.

Means with identical superscripts within a column are not significantly different at $p=0.05$.

Table 4 shows the mean levels of some heavy metals in the fingernails of auto-mechanics and their corresponding reference /pathological values. Table 4 shows that, As was not detected in all categories of automechanics, hence it fell below the reference and pathological values for As in humans. $\mathrm{Pb}, \mathrm{Ni}$ and $\mathrm{Cd}$ in the fingernails of auto-mechanics were below their respective reference and pathological values in all categories of auto-mechanics assessed. However, V levels fell between the reference and pathological values for $\mathrm{V}$. Table 4 shows that the mean concentrations of $\mathrm{Pb}$ in fingernails for auto-mechanics who have practiced for $\leq 5$ years, $\leq 10$ years and $\leq 15$ years $(0.028$ ppm, 0.072 ppm and 0.187 ppm respectively) fall below the pathological limit of $2.0 \mathrm{ppm}$ as stipulated by Micro Trace Minerals (MTM) Germany [30] and Trace Minerals International (TMI) USA [30]. However, the World Health Organization provides a safe exposure limit of $0.2 \mathrm{ppm}$ [32], and going by this limit, automechanics in Makurdi may soon be at risk of leadpoisoning. This is even more so with auto-mechanics who have practiced for $\leq 15$ years as seen in Table 4 . $\mathrm{Ni}, \mathrm{V}, \mathrm{Cd}$ and As levels in the fingernails, all fall below their pathological limits and there is no immediate risk of the toxicities of these metals in the auto-mechanics at the time of the study.

\section{Conclusions}

Auto-mechanics in Makurdi are occupationally exposed to unsafe levels of $\mathrm{Pb}, \mathrm{Ni}, \mathrm{V}$ and $\mathrm{Cd}$ but not so with As. However, there is no immediate threat of heavy metal poisoning in the study population with regards to these heavy metals, as their concentrations in the fingernails of the auto-mechanics assessed were still significantly below their pathological thresholds. However, there is a progressive bioaccumulation of the metals in fingernails of auto-mechanics as the number of years of practice on the profession increases. Arsenic posed the least threat to auto-mechanics as it was not detected in any of the samples.

\section{Acknowledgement}

The researchers are grateful to the Benue State University, Makurdi, for providing the laboratory space and equipment for this research.

\section{References}

[1]. D. Simandan, R. Kitchin, N. Thrift, Industrialization and International Human Geography, Dexter \& Co. Oxford, UK, 2009, pp. 28-32.
[2]. E. Larsen, Impact of industrialization on transportation in the United States, History, Normandale 4 (2016) 12-19.

[3]. D. Bogart, The transport revolution in industrializing Britain: A survey, Royal Press, Cambridge, UK, 2013, pp. 1-3.

[4]. G. Sani, D.B. Ibrahim, A.A. Usman, A. Yahaya, Determination and health implications of heavy metals on the clothes of mechanics in Buzaye automobile village, Sokoto, International Journal of Pure and Applied Science Research 11 (2019) 28-38.

[5]. United States Bureau of Labour Statistics, Department of Labour Report: Occupational employment statistics. Washington DC, USA, 2016, pp. 12-23.

[6]. Bureau of Labour Statistics, United States Department of Labour Occupational outlook handbook, Washington DC, USA 5 (2017) 17-36.

[7]. J. Ford, Skills shortage leaves up to 5,000 automotive industry jobs vacant, The Engineer 2 (2016) 9-15.

[8]. L. Danielson, Gasoline containing lead, Swedish Natural Science Research Council, Ecological Research Bulletin 6 (1967) 8-9.

[9]. O.E. Orisakwe, Environmental pollution and blood lead levels in Nigeria, who is unexposed, International Journal of Occupation and Environmental Health 3 (2009) 315-317.

[10]. A. Atitio, A. Bernard, B.A. Fowler, G.F. Nordberg, Biological monitoring and biomarkers in Handbook on the toxicology of metals, Dekard Publishers 2007, pp. 65-78.

[11]. O.O. Abidemi, Levels of $\mathrm{Pb}, \mathrm{Fe}, \mathrm{Cd}$ and $\mathrm{Co}$ in Soils of automobile workshop in Osun State, Nigeria, Journal of Applied Science and Environmental Management 15 (2011) 279 - 282.

[12]. J.M. Rabe, E.B. Agbaji, Y. Zakka, H.M. Muhammed, A.M. Rabe, Assessment of contaminated soil with some heavy metals in selected auto repair shops in Katsina north western, Nigeria, Journal of. Waste Management and Xenobiotics 1 (2018) 100-113.

[13]. A.A. Pam, R. Sha'Ato, J.O. Offem, Evaluation of heavy metals in soils around auto-mechanic workshop clusters in Gboko and Makurdi, Central Nigeria. Journal of Environmental Chemistry and Ecotoxicology 5 (2013) 298-306.

[14]. E.N. Ojiako, M.N. Okonkwo, Analysis of heavy metals in soil of mechanic workshop in Onitsha metropolis, Advances in Applied Science Research 4 (2013) 79-81 
[15]. A.J. Adebayo, T.J. Jayoye, F. Adejoro, I.O. Ilemobayo, L. Labunmi, Heavy metal pollution of auto-mechanic workshop soils within Okitipupa, Ondo State, Nigeria, Academic Journal of Environmental Science 5 (2017) 215-223.

[16]. Z. Grzegorz, J.S. Bargłowicz, S. Tomasz, A. Kuranc, A. Kamińska, Designation of chosen heavy metals in used engine oils using the XRF method, Polish Journal of Environmental Studies 24 (2015) 2277-2283.

[17]. M.N. Rashed, F. Hossam, Heavy metals in fingernails and scalp hair of children, adults and workers from environmentally exposed areas at Aswan, Egypt, Environmental Bioindicators 2 (2007) $131-145$.

[18]. U. Shan, N. Ikram, Heavy metals in human scalp hair and nail samples from Pakistan: influence of working and smoking habits, International Journal. of Chemical and Biochemical Science 1 (2012) 5458.

[19]. B.I. Adejumo, M.O. Isu, G.A. Uchuno, U. Dimkpa, A.M Emmanuel, O.M. Oke, H.O. Ikenazor, M.V. Hamidu., U.I. Abdulkadir, K.I. Omosor, Serum level of lead, zinc, cadmium, copper and chromium among occupationally exposed automotive workers in Benin city, International Journal of Environmental Pollution. Research 5 (2017) 7079.

[20]. J. Clausen, S.C. Rastogi, Heavy metal pollution among autoworkers, British Journal of Industrial Medicine 34 (1977) 208-215.

[21]. O.V. Akpoveta, S.V. Osakkwe, Determination of heavy metals in refined petroleum products, IOSR Journal of Applied Chemistry 7 (2014) 121-129.

[22]. V. Kumar, A.K. Abbas, J.C. Aster, Environmental and nutritional diseases in Robins basic pathology, 9th Edn., Elsevier, Philadelphia, USA, 2013, pp. 22-28.

[23]. B.W.L. Graham, Exposure to heavy metals in the workplace, Journal of Royal Society of New Zealand 8 (2017) 53-55.

[24]. S.G. Dharma, R.T. Roychowdhury, D. Chakraborti, Arsenic and other elements in hair, nail, skin/scales of arsenic victims in West Bengal,
Indian Science of the Total Environment 3 (2004) 33-47.

[25]. H. Mikasa, Y. Suzuki, N. Fujii, K. Nishiyama, Adsorption and elution of metals on hair, Biology of Trace Elements Research 16 (1988) 59-66.

[26]. G. Samanta, S. Ramesh, R. Tarit, C. Dipankar, Arsenic and other elements in hair, nails, and skin scales of arsenic victims in West Bengal, Indian Science of the Total Environment 3 (2004) 33-47.

[27]. J.O. Jacob, T.B. Paiko, B.M. Yusuph, F.O. Falowo, Lead, copper and zinc accumulation in soils and vegetables of urban farms in Minna, Nigeria, International Journal of Chemical Science 2 (2009) 2006 - 2015

[28]. R. Mehra, M. Juneja, Fingernails as biological indices of metal exposure, Journal of Biological Science 30 (2005) 253-257.

[29]. United States Department of Labour. Occupational Safety and Health Administration (OSHA) Permissible Exposure Limit- Annotated Tables. Retrieved on $7^{\text {th }}$ Feb. 2020 from: https://www.osha.gov/dsg/annotated-pels/tablez1.html\#z-1

[30]. E. Blaurock-Busch, M.B. Yvette, Comparing the metal concentration in the nails of healthy and cancer patients in the Malwa region of Punjab, India with a random European group, British Journal of Medicine and Medicinal Research 5 (2015) 480-498.

[31]. A.F. Nada, M.B. Al-Easawi, A.H. Hassanein, Determination of heavy metal concentrations in nails of car workshop workers in Bagdad, Journal of American Chemical Science 13 (2017) 58-64.

[32]. M.N. Rashed, F. Hossam, Heavy metals in fingernails and scalp hair of children, adults and workers from environmentally exposed areas at Aswan, Egypt, Environmental Bioindicator 223 (2007) 131-145.

Received: 14.09 .2020

Received in revised form: 27.01.2021

Accepted: 30.01.2021 